\title{
The Role of Rainfall Variability in Reservoir Storage Management at Shiroro Hydropower Dam, Nigeria
}

\author{
Suleiman, Y.M $\mathbf{M}^{1}$ and Ifabiyi, I.P $\mathbf{2}^{*}$ \\ ${ }^{1}$ Department of Geography, Federal University of Technology, Minna, Nigeria. \\ ${ }^{2}$ Department of Geography and Environmental Management, University of Ilorin, Nigeria \\ (*tokunifabiyi@yahoo.com).
}

\begin{abstract}
Reservoir operation and management is usually patterned after the background of long standing water resources management experience. Reservoir management for optimum power production at any hydropower station requires constant assessment of the quantity of available water. The hydrographic responses of flow monitoring and statistical analysis of instrumental hydro-met records, especially rainfall and stream flow provide the necessary springboard for sound operational decisions. Statistical analysis of hydro-meteorological data (rainfall, inflow, reservoir storage and turbine release) at Shiroro dam were carried out with the aim of detecting spatiotemporal trends. Correlation and regression analysis were used to develop models for the variables. The correlation of between 0.120 and 0.774 revealed favourable relationships between the variables. This has invariably affected reservoir storage at the dam as excess water is released from the dam to sustain power generation over the years. It is recommended that dam operators optimize the release of water from Shiroro dam and ensure continuous monitoring of changes in hydro-meteorological variables to provide early warning systems for effective performance of the dam and to protect downstream environment.
\end{abstract}

Keywords: Rainfall Variability, Reservoir Management, Environment, Dam, Storage.

\section{INTRODUCTION}

Climate can be defined as average weather over long period of time; say 30-35 years. It can be explained mostly easily in terms of annual or seasonal variations in temperature and precipitation. Observed collectively, however, climate is not a static feature that can be described once and for all by averages of weather variables over specified length of time. It is continuously evolving on a variety of temporal and spatial scales as a result of a complex system of internal dynamic interactions (Ayoade, 1983, 2003).

The hydrological behavior of rivers in the West African sub-region is influenced by a climate that is dependent on an annual cycle of two air masses, i.e., the Northeast trades from the Sahara region and the Southwest Monsoon from the Atlantic (Hastenrath, 1990). Indeed, studies have shown that runoff in West Africa responds sharply to rainfall events (Ledger, 1964, 1969; Ifabiyi, 2004, 2011b, 2011c). A marked rainy and dry season in conformity with the prevailing winds characterized the climate (Umoh, 1995). In general, the amount and duration of the rains 
also decreases from the South of the Kaduna basin northwards except where there are relief or local microclimatic modifications. Records of rainfall-runoff relations for the study area suggests some level of variability in runoff due to rainfall variability; a condition which may impact on reservoir water balance (PHCN, 2010).

Variability in rainfall and its impact on reservoir storage is no longer a speculation. The effect is real and has far reaching implications. About $85 \%$ of the input into the Shiroro reservoir is rainfall over the basin area, leading some researchers to describe this situation as 'atmospheric controlled' (Sadauki, 1997). This essentially means that the variability of rainfall over the basin plays a key role in the observed fluctuation in the reservoir storage level. It is therefore, necessary to sensitize people, particularly the reservoir operators about this hydro-meteorological effect. Ifabiyi (2011a) asserted that the performances of hydroelectric dams in Nigeria are below their designed capacities. He identified inefficient reservoir operations to partly explain the low hydropower generation in Nigeria.

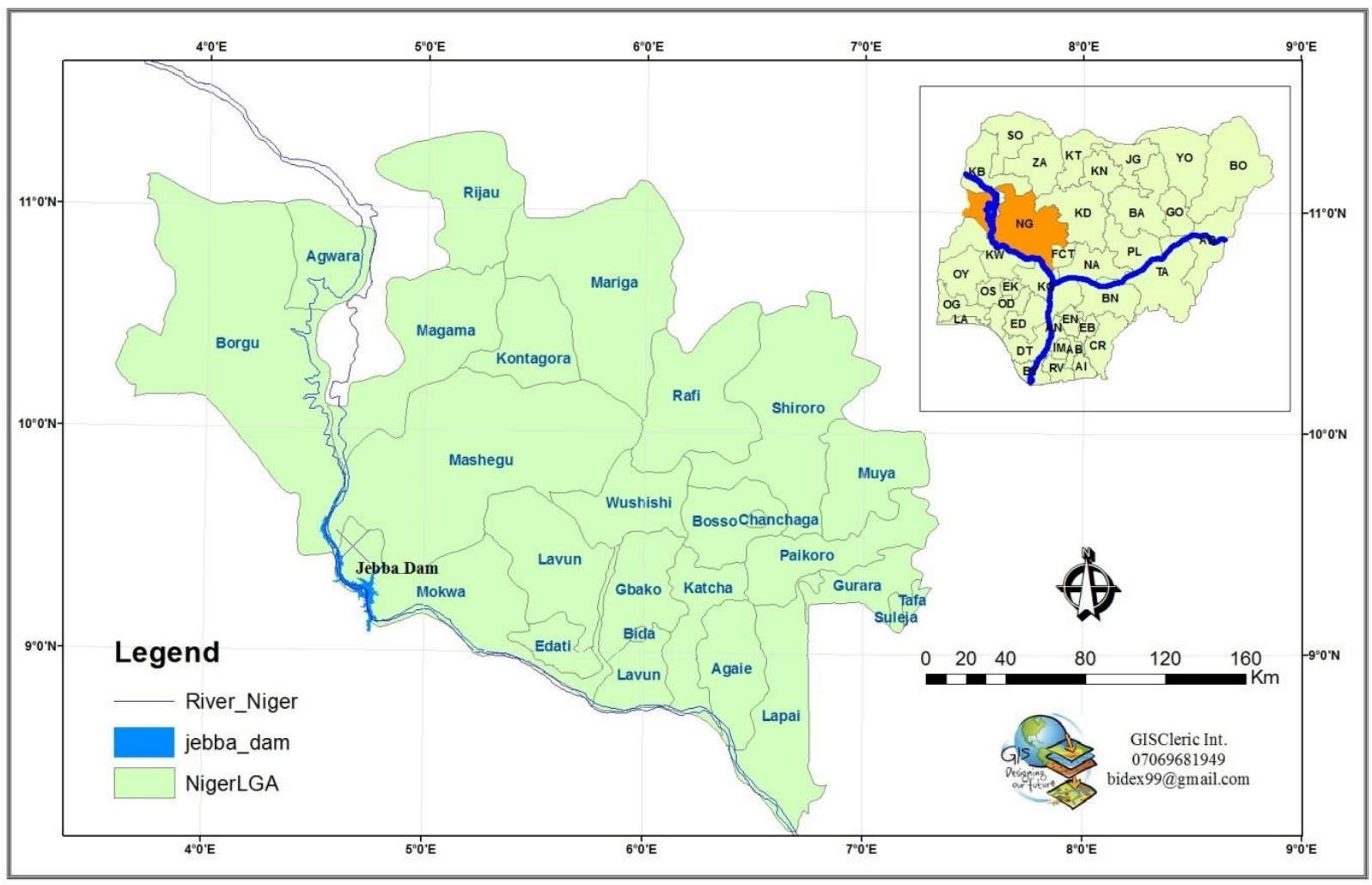

Figure 1. The Middle Niger River Basin. 
The paper focuses on the role of variability in rainfall as it relates to reservoir storage management at Shiroro dam in Nigeria. The objective is to develop functional hydrological relationship between (rainfall, inflow, reservoir storage and turbine releases) over the dam. This will provide scientific basis for operational decisions which can lead to optimum power plant utilization.

\subsection{The Study Area}

The study area is the Shiroro dam reservoir. It is located on River Kaduna, Nigeria on the intersection of latitude $09^{0} 58^{\prime} \mathrm{N}$ and longitude $06^{0} 50^{\prime} \mathrm{E}$ (Fig 1). It has a 600 megawatt capacity. The lake basin area is about $320 \mathrm{~km}^{2}$ with total storage volume of about 7 billion cubic meters. The lake has a maximum length of about $32 \mathrm{~km}$.

The general climate of the study area is the Tropical Monsoon (Am) characterized by alternate wet and dry seasons, with rainfall occurring in the rainy season months of May to October. Temperatures are relatively high throughout the year hovering between $27^{\circ} \mathrm{C}$ and $35^{\circ} \mathrm{C}$, and with an average basin evaporation of 49.28 million cubic meters. .

\section{MATERIALS AND METHODS}

Secondary data were used in this study. The parameters used were sampled for 20 years (19902009) which mark the length of available record as Shiroro dam was built in 1990. Monthly and annual rainfall, reservoir inflow, turbine release and reservoir storage data for Shiroro dam in Nigeria obtained from the dam station and the Nigerian meteorological services were utilized.

Both descriptive and inferential statistical methods were used in data interpretation. The descriptive methods include mean, frequency analysis and graphs.

The calculated mean was done using equation 1.

$$
\mathrm{X}=\frac{\sum^{N} \alpha}{N}
$$

Where $\mathrm{X}$ is the observed parameter, $\Sigma$ is the summation symbol and $\mathrm{N}$ is the number of observations.

Correlation coefficients of the main meteorological variable (rainfall) on hydrologic and reservoir variables were computed to determine the strength of the relationship between the variables. These variables are: rainfall, reservoir inflow, reservoir storage and turbine release. 
Afterwards, the regression analyses of the correlated variables were done to develop regression model after equation 2 .

$$
y=a x+b
$$

Where, $\mathrm{X}=$ time (year), $\mathrm{a}=$ slope coefficients and $\mathrm{b}=$ least square estimates of the intercept.

\section{RESULTS AND DISCUSSION}

Table 1 shows the monthly rainfall statistics of Shiroro dam. The mean annual rainfall of Shiroro is $1,254.1 \mathrm{~mm}$ with standard deviation of $244.5 \mathrm{~mm}$ and a coefficient variation of $19.5 \%$ between $1990-2009$.

Table 1. Rainfall Statistics over Shiroro Dam.

\begin{tabular}{|lccccccccccccc|}
\hline & Jan & Feb & Mar & Apr & May & Jun & Jul & Aug & Sep & Oct & Nov & Dec & $\begin{array}{l}\text { Rainy } \\
\text { Season }\end{array}$ \\
\hline $\begin{array}{l}\text { Mean } \\
\text { Rainfall } \\
\text { (mm) }\end{array}$ & 0.3 & 2.9 & 17.2 & 79.8 & 151 & 185.4 & 256.4 & 310.1 & 271.2 & 80.1 & 0.1 & 0.1 & $\mathbf{1 2 5 4 . 1}$ \\
\hline $\begin{array}{l}\text { \% of } \\
\text { Annual } \\
\text { Rainfall }\end{array}$ & 0 & 0.2 & 1.3 & 5.9 & 11.1 & 13.6 & 18.9 & 22.9 & 19.9 & 5.9 & 0 & 0 & $\mathbf{9 3 . 0 \%}$ \\
\hline $\begin{array}{l}\text { Standard } \\
\text { Deviation } \\
\text { (mm) }\end{array}$ & 1.8 & 9.2 & 25.9 & 14.9 & 64.5 & 50.2 & 76.4 & 75.4 & 96.6 & 76.2 & 0.9 & 31.9 & $\mathbf{2 4 4 . 5}$ \\
\hline $\begin{array}{l}\text { Coefficient } \\
\text { of Variation } \\
\text { (\%) }\end{array}$ & 671 & 316 & 151.3 & 18.6 & 42.7 & 27.1 & 29.8 & 29.8 & 24.3 & 35.6 & 95.2 & 23.5 & $\mathbf{1 9 . 5}$ \\
\hline
\end{tabular}

(Source: Computed from PHCN Hydro-meteorological Data (2013)).

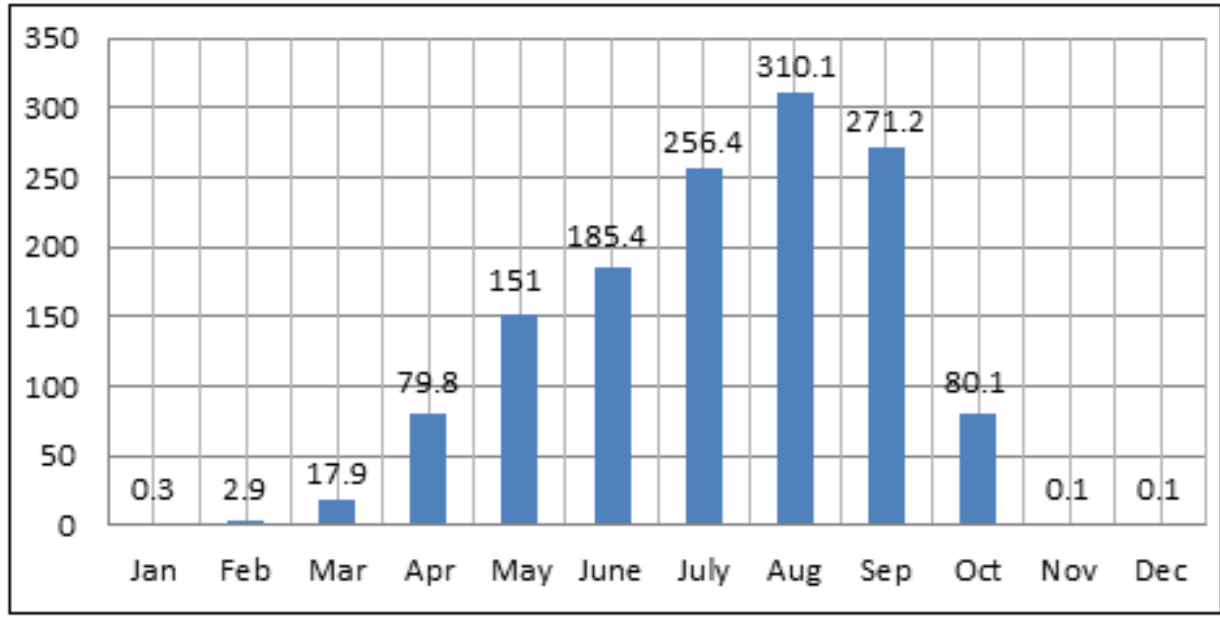

Figure 2. Mean monthly rainfall (mm) distribution (1990-2009) and pattern of rainfall distribution at Shiroro Dam.

(C) CNCS, Mekelle University 
The rainy season coefficient of variation of $19.5 \%$ at Shiroro dam compares favorably with $19 \% \mathrm{t}$ to $23 \%$ obtained by Bunting et al. (1976) for five locations in the interior of West Africa. This suggests that rainfall is entirely concentrated in the rainy season months of May to October (Fig 2).

The low annual coefficient of variation in rainfall suggests that rainfall is less variable from year to year and that variability is greater between the months of May to October which coincides with rainy season, when more than $92 \%$ of annual rainfall is recorded.

The Kaduna River, upon which Shiroro hydropower dam is located, has a single flood regime. This is a characteristic stream flow pattern of most rivers and streams in the Guinea Savannah (Umoh, 1995). The perennial constraints of low water levels in Shiroro dam reservoir after rainfall cessation in October have therefore been accepted as normal; since reservoir operation is usually patterned after a long standing water resource management experience. Consequently, between late October of any year and following rainfall cessation period until July of the following year, flow duration is usually low (Fig 3).

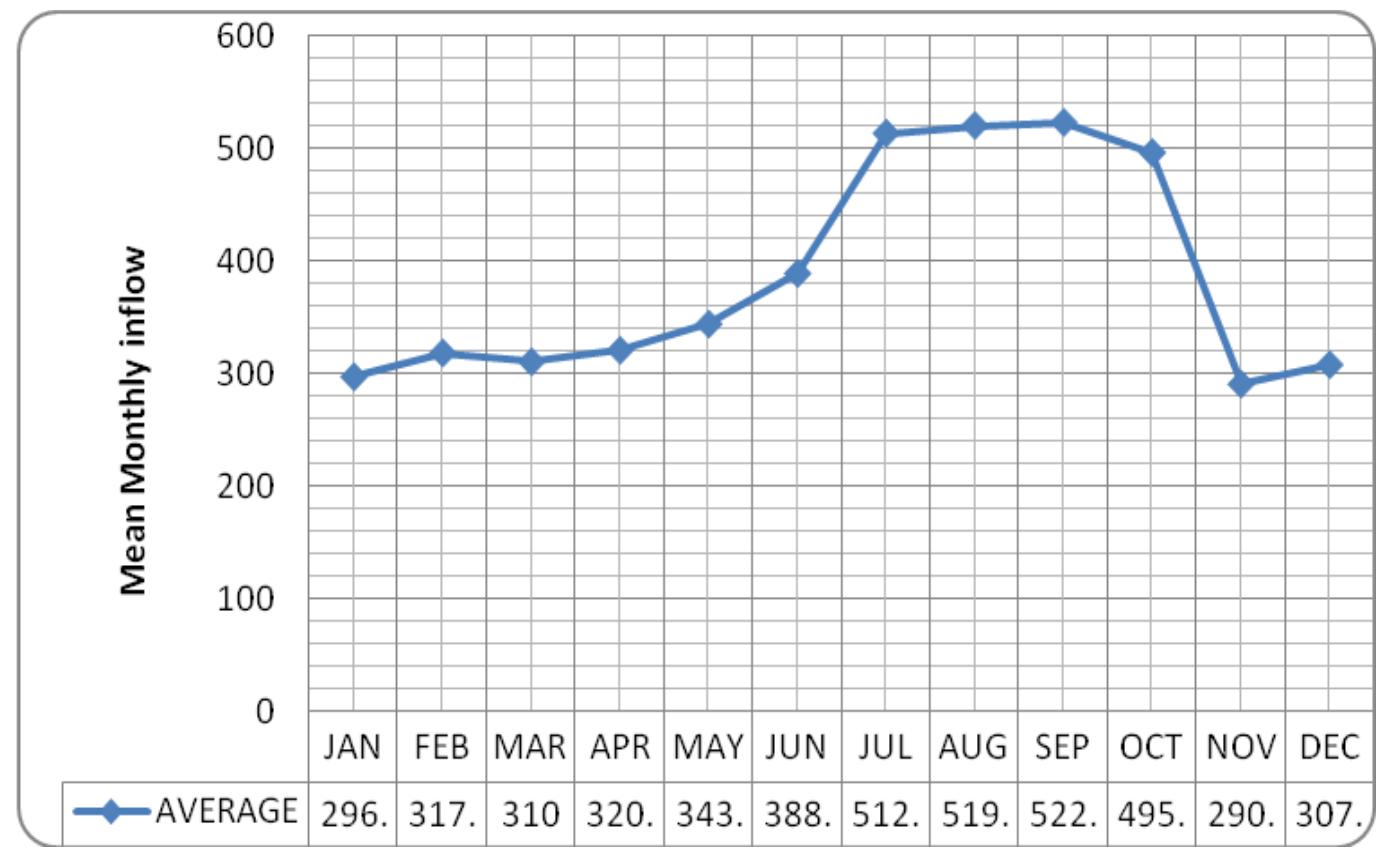

Figure 3. Shiroro mean monthly inflow distribution.

\subsection{Relationships between Rainfall Distribution and Reservoir Hydrology}

The correlation coefficients between rainfall and other hydrologic and reservoir variables for Shiroro dam is presented in table 2. 
Table 2. Correlation coefficient between rainfall and selected Reservoir variables.

\begin{tabular}{|lc|}
\hline Variable & Correlation Coefficient \\
\hline Rainfall $(\mathrm{mm})$ & 0.770 \\
\hline Reservoir inflow $\left(\mathrm{m}^{3} / \mathrm{sec}\right)$ & 0.439 \\
\hline Reservoir storage $\left(\mathrm{m}^{3} / \mathrm{sec}\right)$ & 0.105 \\
\hline Turbine release $\left(\mathrm{m}^{3} / \mathrm{sec}\right)$ & 0.120 \\
\hline
\end{tabular}

The results indicate a significant positive uptrend in rainfall during the study period. A correlation coefficient of rainfall of 0.770 reveals a very strong relationship. The moderate rise in inflow of about 0.439 (44\%) indicated non-significant decrease in inflow into Shiroro dam (Fig 4). The turbine release of about $12 \%$ and the corresponding increase in reservoir storage of $11 \%$ (Figs 5 and 6) has helped maintain all year round power generation at the dam. This has positive effect in the dam operations unlike the situation at Kainji dam, where Oluwatosin and Adeyemo (2011) asserted that the generous turbine release at Kainji hydropower dam has been propitious as it has helped maintain hydropower generation from the dam over the years, thus having an insidious effect on the operation of the dam as it resulted in the significant drop in the storage of the dam.

The analysis of trends in both rainfall and inflow indicates that the Shiroro dam which is located within the Kaduna River basin enjoys annual rainfall amount of between 1,110mm and 1,500mm (Umoh, 1995; Suleiman, 2013). This pattern of annual rainfall distribution is reflected in the surface runoff yield into the Shiroro dam.

The result of the regression model is presented in table 3, while the plots showing the analyzed trend of the variables are presented in figures 4-6.

Table 3. Trend line equations.

\begin{tabular}{|ll|}
\hline Variable & Equations \\
\hline Rainfall $(\mathrm{mm})$ & $y=0.007 x+6.03$ \\
\hline Reservoir Inflow $\left(\mathrm{m}^{3} / \mathrm{sec}\right)$ & $y=0.811 x-210.2\left\{\mathbf{R}^{2}=43.9\right\}$ \\
\hline Reservoir Storage $\left(\mathrm{m}^{3} / \mathrm{sec}\right)$ & $y=5.735 x+2248.0\left\{\mathbf{R}^{2}=10.5\right\}$ \\
\hline Turbine Release $\left(\mathrm{m}^{3} / \mathrm{sec}\right)$ & $y=0.811 x+160.2\left\{\mathbf{R}^{2}=12.5\right\}$ \\
\hline
\end{tabular}

The three months, July, August and September, together represent the period of highest rainfall at Shiroro and consequently significant reservoir inflow harvest. This has significant positive impact on reservoir storage. 


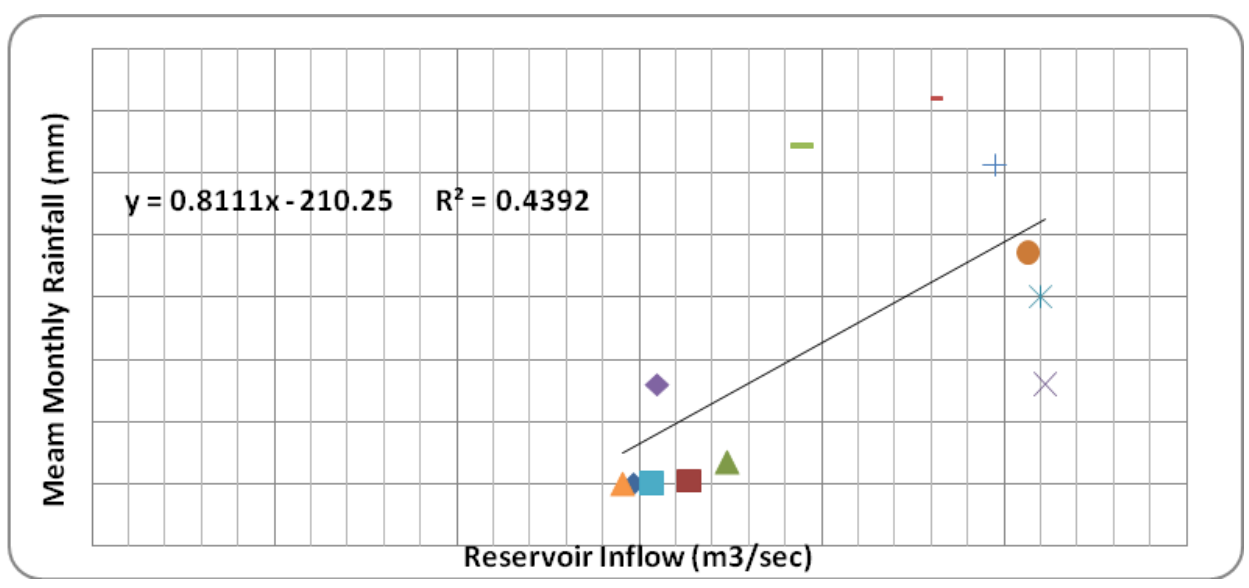

Figure 4. Trend of mean monthly rainfall and Reservoir inflow.

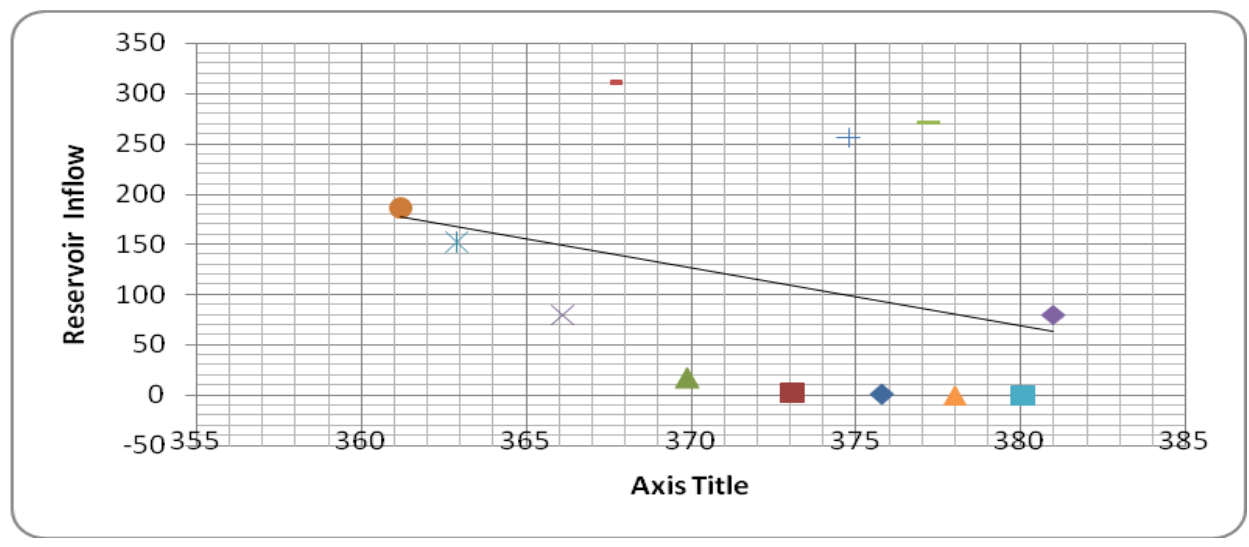

Figure 5. Trend of mean monthly rainfall and Reservoir storage.

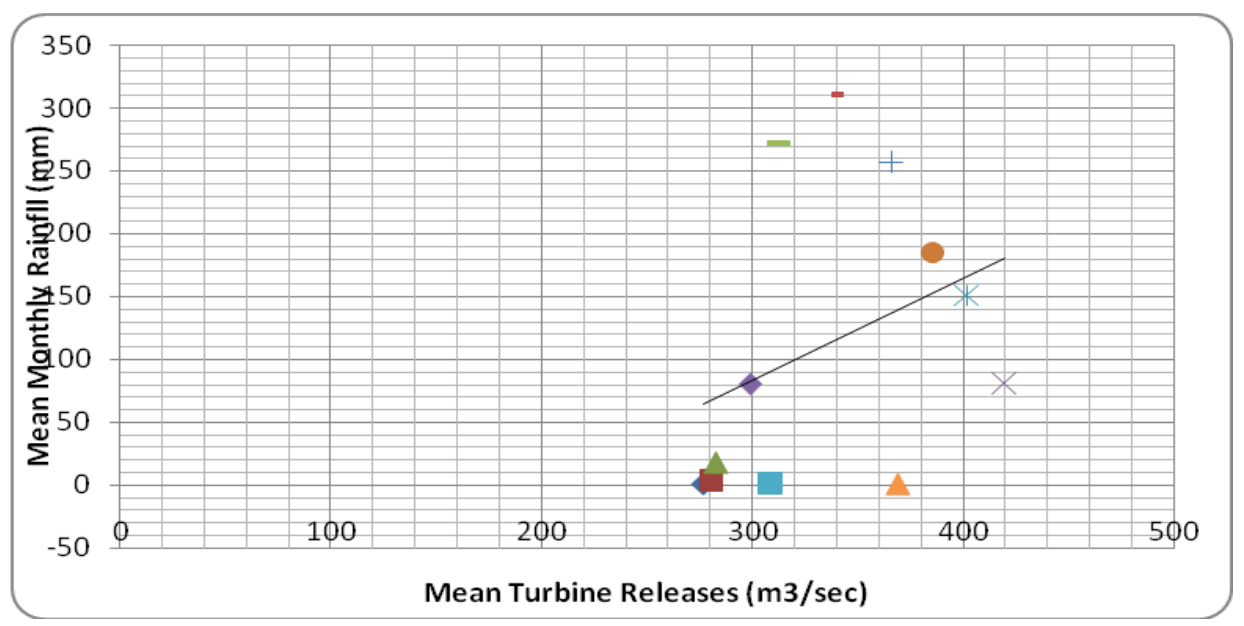

Figure 6. Trend of mean monthly rainfall and Turbine release. 
In subsequent months from October until May (the period of cessation and onset) of the following year rainfall season, water supply for power generation is restricted mainly to whatever is available as storage. Strong limitations are therefore, imposed on power generation at Shiroro after rainfall cessation in all hydrological year. Water use pattern always takes cognizance of this trend in the annual reservoir filling and emptying cycles (PHCN, 2010).

\section{CONCLUSION AND RECOMMENDATIONS}

The results of the analyses indicated a significant uptrend in the amount of rainfall since the commissioning of the lake in 1990. It also reported a strong and positive association between rainfall characteristics and the examined reservoir variables (reservoir inflow, reservoir storage and turbine release

Therefore, it may be concluded that the non-significant variation in rainfall amount as a result of the uptrend in rainfall amount, favors increased reservoir inflow and thus increase in reservoir storage. The optimization of turbine release as part of the operation rule for careful water management also safeguarded reservoir storage that sustain year-round power generation at Shiroro dam. It is therefore recommended that dam operators maintain water optimization policies, ensure continuous monitoring of the various hydro climatic variables to provide early warning systems for effective performance of the dam and to protect downstream environment from hydrologic mishaps. In addition, there should be consideration for commencement and development of a pump water storage systems such that the tail water can be re-use particularly during periods of low inflow. This is imperative because the Shiroro dam project is a medium to high-head scheme.

\section{ACKNOWLEDGEMENTS}

We appreciate the authorities of the Power Holding Company of Nigeria for the data used in this study.

\section{REFERENCE}

Ayoade, J.O. 1983. Introduction to Climatology for the tropics. John Wiley, London.

Ayoade, J.O. 2003. Climate change: A synopsis of its nature, causes, effects and management. Vantages Publishers, Ibadan. 
Bunting, A.H., Dennettt, M.O., Elston, J \& Milford, J.R. 1976. Rainfall trends in the West African Sahel. Quarterly Journal of the Royal Meteorological Society, 102: 59-64.

Hasternrath, S. 1990. Decadal-Scale Change of Circulation in the Tropical Atlantic Sector Associated With Sahel. International Journal of Climatology, 10: 459 - 472.

Ifabiyi, I.P. 2004. Runoff characteristics and its implication to water resources management in the upper Kaduna catchment. Ph.D Thesis, Department of Geography University of Ilorin, Ilorin (unpubl.).

Ifabiyi, I.P. 2011a. Contributions of Reservoir Elements to Monthly Electricity Generation in the Jebba Hydropower Reservoir, Nigeria. Ozean Journal of Applied Sciences, 4(3): 251-263.

Ifabiyi, I.P. 2011b. Response of total runoff to basin variables in dry years in the upper Kaduna basin, Nigeria. Journal of Meteorology and Climate Science, 9(1): 8-17.

Ifabiyi, I.P. 2011c. Response of groundwater to basin variables in the Upper Kaduna catchment. Global Journal of Human Social Sciences, 11(6): 1-11.

Ledger, D.C. 1964. Some hydrological characteristics West African rivers. Transaction of the Institution of British Geographers, 5: 73-90.

Ledger, D.C. 1969. The dry season characteristics of West Africa rivers. In: M.F. Thomas and G.W. Whittington (eds.), Environment and Land Use in Africa. Methuen Publishing Co., pp 88-102.

Oluwatosin, O \& Adeyemo, J. 2011. The Role of Global Warning in Reservoir Storage Drop of Kainji Dam in Nigeria. International Journal of the Physical Sciences, 16(9):4614-4620.

Power Holding Company of Nigeria (PHCN). 2010. Hydrological Data in Reservoir Management, Departmental Paper, Hydrology Unit, Shiroro Dam, Nigeria (unpubl.).

Sadauki, A. S. 1997. Hydrological Analysis and Water Management over the Niger Basin. Ph.D Thesis, Department of Geography, Federal University of Technology, Minna, 180p (unpubl.).

Suleiman,Y.M. 2013. Impact of climate on hydropower generation in the lower Niger River Basin, Nigeria. Ph.D Thesis, Department of Geography and Environmental Management, University Of Ilorin, Ilorin, 184p (unpubl.).

Umoh, U.T. 1995. Analysis of Rainfall-Stream flow in Part of the Niger Basin, Guinea. Savanna Belt of Nigeria. Ph.D Thesis, Department of Geography, Federal University of Technology, Minna, 187p (unpubl.). 